\title{
Entrepreneurs of the self: the development of management control since 1976
}

\begin{abstract}
This review article considers some of the key management control articles published in AOS through the theoretical lens of Foucault's 1978/9 lectures on neo-liberalism and biopolitics. In these lectures Foucault analyses the shift from classical liberalism to what he describes as American neo-liberalism, the birth of biopolitics and the understanding of humans as entrepreneurs of the self. Foucault set out in the late 1970s what is now strikingly apparent in 2015 -- the spread of neo-liberalism universally to domains which were previously thought to be "non-economic", specifically, and for the purposes of this paper, to human-beings.
\end{abstract}


Since AOS's inauguration in 1976, accounting, organisations and society have each undergone significant changes. AOS began at the tail end of Fordism and the early days of the neo-liberal revolutionary era. During AOS's lifetime, various forms of neo-liberalism have become ubiquitous, and the economic elites so powerful, that capitalism has followed a path of increasing economic, political, and cultural domination, arguably, to the point that, today, it controls the most intimate strands of every living body in all corners of the world (Hardt and Negri , 2001). The injurious effects of neo-liberalism -- intensified inequality (Piketty, 2014), the unethical commercialization of arenas previously considered inappropriate for marketization (for example Cooper and Taylor, 2005; Taylor and Cooper, 2008), and the economic havoc unleashed on the economy by the ascendance and liberty of finance capital, (Brown, 2015; Cooper, 2015), have been widely analysed. The concern of this paper is with the management control literature in AOS, and more specifically with AOS's reflection of management control's role as a portal and/or agent for the globally ubiquitous spread of neo-liberalism and particularly on its consequent impact on many employees, which, as will be argued in the paper, have been profound and deleterious.

In a powerful account of work in the neo-liberal era, Cederstrom and Fleming (2012) argue that, in a wide range of occupations, both at the top and the bottom of organisational hierarchies, work is experienced as a "living death". The majority work for longer hours, less pay, fewer benefits, less security, and less promise of retirement and upward mobility (Brown, 2015). But there is something deeper at play. Neo-liberal mentality has reconfigured humans from being waged/salaried employees to human capital --entrepreneurs of the self (Foucault, 2010). In a sense, life itself has been put to work $^{1}$-- our sociality, imagination, resourcefulness, and our desire to learn and share ideas. Corporations increasingly strive to harness these very human characteristics to drive value but neo-liberal subjects have a hyper individualised expectation placed upon them to maximise returns on themselves. In practice, the majority have both a boss who gives orders, and an overwhelming management control system to deal with ${ }^{2}$. It could be that this dual (and contradictory) pressure, to be entrepreneurial while also being closely controlled, is at least part of the reason behind the anguish suffered across all organisational levels described by Cederstrom and Fleming (2012). This is overlaid by the material conditions of exploitation (O'Doherty and Willmott, 2002), performance related pay, zero-hour contracts, falling real wages, the removal of state safety nets and so on.

Accounting can serve as a crucial technology of neo-liberalism (see for example, Arnold, 2009; Arnold, 2012; Covaleski et al, 2013; Jupe, 2012). It enables the rationalities of neo-liberalism to pass through and thereby transform the organisation and create new organisational practices (Hopwood, 1987) targeted at the workforce. Management control systems play an important role in controlling and providing individualised ranking of "entrepreneurs of the self" as well as providing the technologies which create the growing divisions in wealth and income.

In the transition from Fordism to neo-liberalism, there are accounting continuities and discontinuities; management control continues with the roles it played under Fordism (control, individualisation, providing costing information and so on); but some of its technologies are new and importantly constitute subjects in a very different way. Under neoliberalism people are construed on the model of the firm and are accordingly expected to act in ways that maximize their (human) capital value, through entrepreneurialism, self-investment and/or attracting investors/networking (Brown, 2015).

\footnotetext{
${ }^{1}$ This is biopolitics

2 Under Fordism workers could mentally tell the boss to "fuck off" as they left the factory. Turning-off is no longer an available option -40 years ago weekends and leisure time were still relatively untouched, now the majority take work home with them (Cederstrom and Fleming, 2012).
} 
The notion of "putting life itself to work" was described by Michel Foucault as biopower. Foucault was a professor at the Collège de France from 1971 until 1984 when he died. The rules of the Collège are that professors must annually deliver 26 hours of public lectures. The dominant theoretical perspective in this paper comes from the lectures which Foucault gave for the year $1978 / 9$ on the birth of biopolitics. In these lectures Foucault begins to painstakingly distinguish biopolitics from disciplinary power (Di Vittorio, 2005, 102 - 103; Reyes-Zaga, 2014). Foucault set out in the 1970s what is now blindingly obvious in 2015. Although it is impossible to do justice to Foucault's extraordinarily prescient lectures, this paper re-considers some of the key management control articles in AOS through the theoretical lens of neo-liberalism presented in his lectures. It is also impossible to do justice to every management control paper published in AOS. On the premise that academic research both reflects and constitutes accounting practice, this review paper aims to consider at a micro level the roles and processes of, and the rhetoric behind, accounting's roles in displacing the management function onto newly entrepreneurialised workers at all levels of the organisation. It also considers how work in AOS has dealt with the impact of newly configured management control technologies on the individual and the spaces for resistance. The paper turns first to Michel Foucault's lectures on biopolitics which set out the rationalities of neoliberalism. While these rationalities are important for the argumentation in this paper, the economic context of neoliberalism (capitalism) cannot be ignored. Capitalism dominates the human beings and human worlds it organises (Brown, 2015).

\section{Foucault's biopolitics and neo-liberalism}

Neoliberalism is not stable or unified. It ranges and changes temporally and geographically and is still being made and remade. The problem of defining neo-liberalism is not solved by Michel Foucault's account of it. But Foucault's explanation of neo-liberalism brackets it in a useful way. Foucault conceives neoliberalism as an order of normative reason that, when it becomes ascendant, takes shape as a governing rationality extending a specific formulation of economic values, practices, and metrics to every dimension of human life (Brown, 2015). Brown (2015) notes that this governing rationality involves what Caliskan and Callon $(2009,2010)$ term the "economisation" of heretofore noneconomic spheres and practices, a process of remaking the knowledge, form, content, and conduct appropriate to these spheres and practices. This economization of arenas previously considered as inappropriate for marketization has been considered by academic accounting research (for example Callon, 2009; Muniesa, and Linhardt, 2011; Poon, 2009; Samuel et al, 2005) but while the "market" term "human capital" appears fairly frequently in AOS, it is analysed here as a very specific neo-liberal concept.

\section{Humans as human capital}

Foucault's biopolitics, set out the neo-liberal mode of thought in which humans are reconfigured from being waged employees to entrepreneurs of the self. He states that neo-liberals argue that although classical economists have always seen production as depending on land, capital and labour, that labour has been left either unexplored or dealt with in an abstract way ${ }^{3}$. Foucault discusses the attempts by Theodore Schultz, Gary Becker and Jacob Mincer and other Rational Choice theorists to bring labour into the field of economic analysis in a "non-abstract way". To neo-liberals work must be studied as economic conduct practiced, implemented, rationalized, and calculated by the person who works. The worker is not present in economic analysis as an object-the object of supply and demand-but as an active economic subject. Foucault (2010, pp 223/4) explains that neo-liberal mentality cannot see any reason to work except to produce an income. In their analysis of income

\footnotetext{
${ }^{3}$ Foucault argues that although Marx placed labour at the centre of his theoretical work, the American neoliberals would see Marx's analysis as too "abstract".
} 
neo-liberals refer to the (early twentieth century) definition, of Irving Fisher, who said that an income is simply the product or return on a capital. Under neo-liberalism "Capital" has come to mean a source of future income (Cooper, 2015). From the side of the worker, labour is not a commodity reduced by abstraction to the time which it is used. The neo-liberal understanding of a worker is a conception of capital-ability which, according to diverse variables receives a certain income so that the worker appears as an enterprise for herself. Neo-liberal human capital includes both genetic and acquired elements. The genetic elements, akin to social Darwinism, are such that individuals achieve advantage over others as the result of genetic or biological superiority; the acquired elements include education and other investments in the self. Importantly, inequality, not equality, is the medium and relation of competing capitals. When we are configured as human capital, equality ceases to be our presumed natural relation with one another (Brown, 2015). Humans lose their standing as being simply valuable as humans.

Aside from representing humans as "naturally unequal", the neo-liberal vision of human capital further serves to distort a class perspective. One of the social contradictions of neoliberalism is that the majority are employees -- not just human capital for themselves but also for their employers and/or shareholders. Human capital is at once in charge of itself, responsible for itself, yet an instrumentalizable and potentially dispensable element of the whole. And when humans are cast as capital, labour disappears as a category, as does its collective form, class, taking with it the analytic basis for alienation, exploitation and association among labourers (Brown, 2015, p 38). Moreover, the neo-liberal hyper-individualised rationality serves to efface what Marx described as the forces and relations of production - the capitalist class own the means of production, while the majority can only survive by selling their labour while the owners of the means of production profit from their labour.

The neo-liberal conception of "entrepreneurs of the self" is one in which human action is animated by rewards or future rewards. Foucault (2010, p 270), makes the connection between this and the work of behavioural psychologists like Skinner stating that "...you can see the possibility of integrating within economics a set of techniques, those called behavioural techniques, which are currently in fashion in the United States. You find these methods in their purest, most rigorous, strictest or aberrant forms, as you wish, in Skinner, and precisely they do not consist in analysing the meaning of different kinds of conduct, but simply in seeing how, through mechanisms of reinforcement, a given play of stimuli entail responses whose systematic nature can be observed and on the basis of which other variables of behaviour can be introduced."

\section{The pursuit of individual wealth maximisation as a moral practice}

The neo-liberal understanding of humans as animated by income is supplemented by the belief that individuals should strive to maximize their individual wealth. Rather than seeing individual wealth maximising behaviour as "greedy" -- it is moral. This morality is based upon Adam Smith's invisible hand, which in a neo-liberal grid means that humans maximise social wealth by maximising their own wealth. Foucault states $(2010, \mathrm{p} 277)$ that neo-liberal rationality is that each person is dependent on an uncontrollable, unspecified whole of the flow of things and the world. At the same time, an individual's interest, without her knowing, wishing, or being able to control it, is linked to a series of positive effects which mean that everything which is to her advantage will turn out to be to the advantage of others. What is usually stressed in Smith's famous theory of the invisible hand is the existence of something like providence which would tie together all the dispersed threads. To Foucault (2010), invisibility is absolutely indispensable to neo-liberal argumentation. Invisibility means that no economic agent should try to pursue the "collective good". Political power (the state) must not interfere with this dynamic naturally inscribed in the heart of man. Under this mentality, the state is accordingly prohibited from obstructing market mechanisms, though, for example, the 
payment of unemployment benefits which would distort the efficient functioning of labour markets. The neo-liberal "market" mentality suggests that the role of competition as a disciplining device is reduced if the state pursues social welfare policies" ${ }^{4}$. Foucault argues that from the point of view of the problem of power and of the legitimate exercise of power homo œconomicus is radically new, although, over the last 40 years this conceptualisation of humanity has gradually become doxic.

\section{The accounting implications of the "entrepreneurialisation of people"}

The accounting implications of the "entrepreneurialisation of people" are profound. As Brown (2015, p 36) explains, human capital's "constant and ubiquitous aim, whether studying, interning, working, planning retirement, ..., is to entrepreneurialize its endeavours, appreciate its value, and increase its rating or ranking. In this it mirrors the mandate for contemporary firms, countries, academic departments or journals, universities, media or websites: entrepreneurialize, enhance competitive positioning and value, maximize ratings or rankings." Neoliberalism transmogrifies humanity according to a specific image of the economic. All conduct is economic conduct; all spheres of existence are framed by economic terms and metrics (even when those spheres are not directly monetized). Accordingly, accounting's financial and non-financial performance metrics, ratios, balanced-scorecards and other technologies, play a role in producing an account of the value of our human capital, its ranking, position and so on. From a managerialist perspective accounting metrics hold the promise of an ability to motivate, monitor and rank the endeavours of employees; under neo-liberalism the targets of these metrics are not waged employees but income maximizing entrepreneurial units of human capital.

How to make agents self-monitor and motivate is an enduring management accounting concern (Herzberg, 1968). Baiman (1990) notes that, agency theory states that, it is best if agents selfmonitor in the interests of the principal. It might seem as if accounting metrics which give entrepreneurial human capital units information about their performance rankings so that they can maximize their current and/or future income may be a "solution" to this persistent management problem. Indeed, agency theory's dualism in which the principal is risk-neutral while agents are riskaverse (and so not naturally entrepreneurial) is in some senses made redundant by neo-liberal conceptions of agents. A feature of neo-liberalism is that risk is pushed downwards to the most vulnerable. However, when neo-liberal rationalities overlay the agency perspective, risk-averse agents need to be both made to be more entrepreneurial, and strictly controlled. After all, entrepreneurialism may lead workers to act in ways which are inconsistent with the needs of their employers. Paradoxically then, the neo-liberal view of humanity may invoke more managerialism and tighter management control systems. This would depend upon the power of the groups involved. Work in AOS has rejected technological determinism and economic imperatives as a satisfactory basis for explaining changes in the modes of management control; accounting controls are rooted in struggles as firms attempted to control labour processes in various epochs of

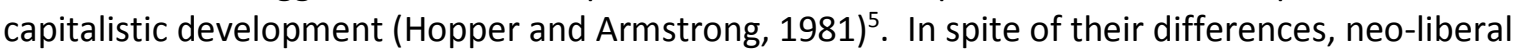
rationality shares a similar methodology to work which adopts the agency perspective.

\footnotetext{
${ }^{4}$ Baiman (1990) gives the example of "human capital" -- a person with skills that are needed in a particular organisation, who cannot be easily replaced - so can demand higher wages from their employer. The corrective to this "market imperfection" would be unemployment (including unemployment of highly skilled people) which would enable the market to function better.

${ }^{5}$ The notion that searches for efficiency under the pressure of competitive markets were the primary drive behind the development of capitalistic organisations and scientific management is highly contentious and has been strongly disputed by historians and radical political economists, (e.g Montgomery, 1979, 1987; Braverman, 1974; Clawson, 1980; Nelson, 1974).
} 
From a methodological perspective, neo-liberal ideas epitomize an extreme form of functionalism ${ }^{6}$-objectivism/behaviourism. Neo-liberal methodology articulates with functionalist research in accounting which has an extremely high degree of commitment to models and methods derived from natural science, have a strong faith in markets, and adopt a Skinneristic atomised view of the individual as responding reflexively to incentive and monitoring schemes (Burrell and Morgan, 1979; Hopper and Armstrong, 1991). The ability to include performance metrics in, for example, performance related pay contracts articulates well to functionalist work's "Skinneristic" preoccupation with the influence of incentive and monitoring systems and contracts on the behaviour of agents (Armstrong, 1991; Eisenhardt, 1985, 1988; Kosnick, 1987). Research which adopted this functionalist methodology grew to become the mainstream or orthodox during the life of AOS.

From its inception, AOS has published work from very different methodological paradigms. It established a space in accounting for non-orthodox (non-functionalist) perspectives to establish themselves so that their possibilities could be explored and understood. AOS was a leader in publishing work (Armstrong, 1985, 1987; Miller and O'Leary, 1987; Hoskin \& Macve, 1986; Loft, 1986; Merino \& Neimark, 1982; Hopwood, 1987; Miller and Napier, 1993) which differentiated itself from orthodox work which saw accounting change as a process of technical elaboration and improvement. AOS showed how organisational accounts are actively constructed as a powerful means for creating a particular economic visibility which facilitated management control along economic lines (Cooper, 1980, 1981; Hopper et al., 1986; Tinker, 1980; Tinker et al., 1982). Further, it showed how accounting facts could be distanced from yet reflect the physical production processes (Cooper and Taylor, 2000; Miller and Napier, 1993). Thus some of the early AOS work on management control systems saw that although accounting functions in organisations, accounting is something which is best understood as in the domain of the social rather than the narrowly organisational.

AOS discouraged academic sectarianism, and encouraged high-quality dialogue and debate. There is a stream of management control research within AOS much of which adopts a neo-functionalist view that management control systems should direct and motivate employees to act in accordance with organisational strategy; if they fail to do so then accounting technologies should be amended. This research is also concerned with the relationship between management control technologies, organisational performance and management satisfaction. Some of this research's large data sets, help to enhance wider understandings of the progressively increased use of and scope of management control systems under neo-liberalism frequently from a managerial perspective. It also to some extent reflects the development of neo-liberal rationalities in the accounting literature. This more orthodox stream of research will be considered next.

\section{Contingency - linking strategy to control systems and organisational performance}

The contingency approach to the study of organisations came into prominence during the 1970s. Organisational research on individual motivation, job satisfaction, leadership style, organisation structure, technology and many other organisational variables was interpreted within the context of a managerially oriented set of propositions, which assert that the effective operation of an enterprise is dependent upon there being an appropriate fit between its internal organisation and the nature of the demands placed upon it by its tasks, its environment and the needs of its members. (Burrell and Morgan, 1979). A stream of work began in the 1970s in AOS and continues to this day, adopts this approach, and is concerned with whether or not a company's strategy or its value drivers align with its management control systems (for example, Chenhall, 2003; Chenhall and Langfield-Smith, 1998; Cadez and Guilding, 2008; Dent, 1990; Dermer, 1990; Gerdin, 2005; Gerdin

\footnotetext{
${ }^{6}$ Ontologically realist; epistemologically positivist; extremely deterministic; methodologically nomothetic.
} 
and Greve, 2004, 2008; Haka, 1987; Hartmann and Moers,1999; Henri, 2006; Ho et al, 2014; Merchant, 1984; Otley, 1980; Perera et al, 1997; Selto et al, 1995; Simons 1987, 1990; LangfieldSmith, 1997). The early focus of this research was on more senior management controls and their alignment with strategy (Langfield-Smith, 1997; Simons, 1987). But gradually reflected the trickle down of management control systems through middle management (Hopper and Armstrong, 1981) to increasingly lower levels of organisational hierarchies (e.g., Abernethy and Lillis, 1995; Abernethy \& Brownell, 1997, 1999; Adler and Chen, 2011; Bisbe \& Otley, 2004; Davila, 2000; Davila, Foster, \& $\mathrm{Li}$, 2009; Ditillo, 2004). This work also charts the introduction and implementation of newer accounting technologies (targeted more at individuals) and mirrors the qualitative change in management control which developed substantially during the life of AOS in both the public and private sector (see for example, Grafton et al, 2010; Habersam et al, 2013; Ho et al, 2014) although, like neo-liberalism itself, there are cultural differences in the rate of adoption of new management control systems (Jansen et al, 2009).

Research into the "linkages" between management control systems, strategy and performance is mixed (Adler and Chen, 2011; Ittner et al, 2003)). The work in AOS demonstrates that while there may be the desire on the part of management to produce (for example) profit maximisation or shareholder value maximization (Chabrak, 2014), that management control systems may produce unintended negative consequence (eg Simons, 1987; Ittner and Larcker, 1997). Negative consequences are frequently explained in functionalist terms - lack of alignment to strategy and so on (Ittner and Larcker, 1997). Interestingly, Ittner and Larcker (1997) specifically found that "employee empowerment" which allows workers to become more entrepreneurial, form teams and select projects without management approval, may prevent organizations from identifying and implementing those improvement projects offering the highest potential contribution to overall business performance.

\section{A critical appraisal of the contingency work in AOS}

The body of AOS work which adopts a contingency approach to management control and/or measures the impact on organisational performance, outlined here, on the whole, could be categorised by Burrell and Morgan (1979) as belonging to the functionalist paradigm which assumes continuing order and pattern and is geared towards providing an explanation of "what is". Newly introduced accounting technologies are simply "taken-for-granted." Research in this paradigm is virtually silent on the impact of management control on the well-being of the workforce. Although a variant of this work built upon Cherns (1978) which was concerned about the quality of working life. Cherns (1978) adopted the position that that a more humane working situation is a functional imperative within the context of the system as a whole. In its depiction of humanity, the contingency work, while not adopting the language of workers as entrepreneurs (although it does use "human capital") does contain some of neo-liberalisms rationalities. It is Skinneristic in its treatment of human actors in its concern to find the most efficient mechanisms to make humans achieve organisational goals. Whether this is in a "humane" way (akin to Cherns, 1978) or through the implementation of techniques with virtually no concern about the impact on workers except in as much as they fulfil organisational objectives.

Most contingency work adopts a regulative stance which is concerned to make piecemeal adjustments and accepts the status quo as given - there are no alternatives to neo-liberalism. Explanation in functional theory is teleological in that functional problems are assumed to call forth their own solution, with no explanation of how this is actually accomplished (Armstrong, 1991).

Research with a very different methodology with respect to management control, perhaps more associated with Burrell and Morgan's sociology of radical change, featured heavily early in the life of 
AOS. This work was clear that accounting reflected and served certain economic and political interests (for example, Cooper and Shearer, 1984; Coveleski and Aitken, 1986; Hopper and Armstrong, 1981; Lehman and Tinker, 1987; Neimark and Tinker, 1986; Toms, 2005; Tinker et al, 1982). Tinker et al, (1982) p 192, stated that the "importance of giving due weight to the social context of accounting becomes even more apparent if we recognize that, to date, when accounting has affected the work-lives of employees, it has done so overwhelmingly on behalf of corporations and employers. Budgeting, motivating, coordinating and planning are methods for controlling the behavior of people within organizations. The traditional areas of cost and management accounting (together with more recent approaches based on industrial psychology and organization theory) have escaped virtually Scot-free from critical social appraisal." In its insistence that it is important to remember that on the whole, large corporations own the means of production and so the majority work for someone else, this early work provides a tool for "remembering" the importance of class in the face of the seeming eradication of class relations by neo-liberal rationalities.

Unlike the more functionalist work in AOS, it is important to the labour process theorists that management power isn't simply taken for granted. Armstrong $(1991, p 6)$ argues that within "the capitalist social relations of production, the most basic contradiction arises because employers and managers are faced with the inescapable problem of achieving co-operative activity by antagonistic means. Because there is always a necessary element of voluntary activity in any system of cooperation this contradiction can never be finally overcome within capitalism." This contradiction applies to management too, Armstrong $(1991$, p 7$)$ argues, "individual managers and "profession" groups may possess short-run interests which are imperfectly aligned with, although not, of course, independent of, those of capital ownership." Nonetheless, it is the role of management to continue to attempt to overcome these social contradictions.

With the development of neo-liberalism, as reflected in the AOS contingency literature noted above, accounting has transformed from cost accounting which was concerned with the calculation of product costings for pricing policy rather than for example manufacturing strategy (Hopper and Armstrong, 1981) towards management accounting and more individualised "human accounting" metrics. In effect there has been a shift towards management accounts targeted at the conduct of individuals rather than (for example) pricing strategy, although this is still important. AOS work which considers the shift in accounting from costing to management control is considered next.

\section{Control and "Normalisation" of Entrepreneurial Subjects - the shift from cost to management accounting}

AOS research provides some compelling albeit necessarily incomplete explanations concerning accounting's role and power in both individualising people and at the same time animating them to "unwittingly collude with power". Work in AOS and elsewhere has been concerned with how individuals seem to so readily accept a reductionist numerical accounting vision of the self (Collier, 2005; Dixon and Gaffikin, 2014; Edgley, 2014; Farjaudon and Morales, 2013; Hammond et al, 2012; Lehman, 2013; Roberts, 2005; 2009; Upton and Arrington, 2012). In a historical analysis of the transformation of "cost accounting" into "management accounting", Miller and Napier (1993) ${ }^{7}$ sets

\footnotetext{
${ }^{7}$ Interestingly, Miller and Napier (1993), charts another important change which occurred after the UK Conservative government election in 1979. Up until this point, there was some momentum behind the production of "value added statements" which portrayed three constituents in the construction of value capital, labour and the state. After 1979, these three arenas were abruptly transformed. In particular, state rhetoric was that the state should shrink, and accordingly not "interfere" in the economic. And the terms on which industrial relations were to be operated were fundamentally and painfully altered according to the neoliberal rationality that nothing should be allowed to interfere in markets.
} 
management accounting within a complex set of practices (IQ scores, BMI indices, and so on) which place individuals within statistical distributions, and measure and calibrate them according to norms. Once (for example), a BMI score is taken to represent a very complex human being, it is only a short step to accepting a management control metric as representing the ranking and/or value of a human. Numerical (and other) rankings are ubiquitous under neo-liberalism. Fourcade and Healy (2013) argue that in the neoliberal era market institutions increasingly use actuarial techniques to split and sort individuals into classification situations that shape life-chances. More recent work in AOS attests to the ubiquity of performance measures (Dambrin and Robson, 2011; Artz, Homburg, and Rajab 2012).

In terms of the "power" of numerical metrics more generally, Knights and Collinson (1987) identify the class-specific power of accounting, by showing the disciplinary power of financial accounts over male manual workers. Financial numbers refer to an economic reality to which male manual workers are especially sensitive and vulnerable. Although workers resisted psychological discipline from human resources managers, workers self-subjected to the numbers, as they share materialist and unambiguous characteristics with them.

There is an emotional edge to accounting which is seldom recognised (Boedker and Chua, 2013). Some of the most powerful work in AOS, which considers the potent impact of performance metrics on individual angst and emotions, draws from Lacanian psychoanalysis (Lacan, 1979). Lacan's human subject is an anxious one with imaginary relations and an empty core, whose continuing and overwhelming desire is for "confirmation of selfhood". Unfortunately, nothing can ever truly satisfy this desire because recognition from others is always fleeting and temporary. A Lacanian insight into the implications of the atomised reductionist management accounting field of vision, is that accounting metrics become mirrors in which individual humans are reflected. Management accounting constructs a field of visibility through which individuals and/or groups can be made visible and accordingly compared, differentiated, hierarchized, homogenized and/or excluded/fired (Roberts, 2005). According to Lacanian theory individuals have a preoccupation with how they are seen and judged and this preoccupation is intensely individualising. Numerical metrics can offer the hope of fulfilling our overwhelming desire for reflection (I would kill to achieve the illusive "10" rating). Accounting can set standards and measures which tell us what is normal, reflect us, measure us, aim to embed social hierarchies and understandings within us, make us fearful, direct our efforts and offer the hope of fulfilling our insatiable desire for reflection and to control. The effects of accounting control systems are dependent upon the context in which they operate. Identification collapses the space for resistance for it is through such identification that we inscribe the power relation within the self (Roberts, 2005). Although resistance is integral to this process, in part through the felt necessity to defend our imagined autonomy against the intrusion of others such resistance can take the form of what Zizek $(2000, \mathrm{p} 252)$ calls a 'deadly mutual embrace' that binds me ever more tightly to that which I resist (Roberts, 2005).

Aside from its explanation of how accounting metrics come to have an extreme impact on those subjected to them, Lacan offers a further insight into management control from the perspective of those with organizational superiority over others. The Lacanian subject is desperate to control or at least to feel in control. Lacan suggests that this kind of desire is what Freud was trying to grasp in the concept of death drive, the drive towards negativity (Cooper, 1992). While management control systems will never be able to satisfy the desire for "confirmation of selfhood" or to make us feel completely in control, increasingly sophisticated management control systems are incredibly seductive in that they continually offer the promise of complete control. This understanding reflects some of the contingency work's finding that management are satisfied with performance management sysems (Chenhall and Langfield-Smith, 1998; Govindarajan, 1988; Govindarajan and 
Gupta, 1985; Ittner and Larcker, 1997; Shields and Shields, 1998). This appears to be the case except when managers are subject to them (Ittner and Larcker, 1997).

\section{Summary}

This section draws from work which describes the complex, seductive and potentially destructive relationship between management control information and human-beings. Lacanian theory provides an explanation of the power of management control technologies that differs from versions of disciplinary power that rely upon discourse to describe the ways in which power is constitutive of subjectivity (Alvesson and Karreman, 2000; Grant et al., 1998; Hardy et al., 2000). In this, the Lacanian work provides an important addition to Foucault's conception of the construction of the entrepreneurial subject. Individualised metrics will be more powerful in a society obsessed by rankings, individual accomplishment and entrepreneurialism. It is therefore essential when trying to understand the practices of accounting in a neo-liberal world to investigate the operation of accounting at the level of practice. There are many ways in which humans might react to different management control systems in different organisational, political and economic contexts. The next section accordingly considers the insights derived from some of the key research into the practice of management control published in AOS.

\section{Accounting in practice}

One of the key AOS articles which presented a longitudinal case analysis of a company which attempted to make its workers more entrepreneurial is Miller and O'Leary (1994). This section pays particular attention to this case and other cases which consider management accounting practice. In particular it considers the relationship between the constitution of subjectivity and the economic system. With regards to the economic, it teases out some of the social contradictions of neoliberalism exposed by the work in AOS.

\section{Caterpillar}

Miller and O'Leary (1994) present a case study which sets out the endeavour to reconstruct workers as entrepreneurial units of human capital (albeit in embryonic form in the guise of "economic citizens") in the Decatur plant of US multinational Caterpillar in their "Plant With a Future (PWAF) programme. The workforce/new economic citizens ${ }^{8}$ were to be empowered/entrpreneurialised so as to be able to confront the exigencies of global competition in a direct mediated and personal fashion. The vision presented in Miller and O'Leary (1994) is optimistic and very much in line with what Boltanski and Chiapello (2005) argue is the "new spirit of capitalism" in which capitalism recognises that it will face increasing problems unless it provides some grounds for hope to those whose engagement is needed for the system to operate. The "hope" was that the changes would create a "virtuous circle" aligning changing work practices and management control systems to improve both the profitability of Caterpillar and the global competitiveness of the region and the nation. For many of the workforce, the hope was to preserve their jobs.

The Caterpillar case sets out how the physical reconfiguration of the factory and the formation of new manufacturing cells/modules were important for the "creation of entrepreneurs". The new cells/modules were to be understood as small businesses or spaces for collective entrepreneurship by their workers (cell proprietors). Caterpillar management put forward a case to the workforce that

\footnotetext{
${ }^{8}$ Miller and O'Leary (1994, p 18) state that given "appropriate regulatory institutions, shop-floor workers, supervisors and middle-managers can become new kinds of economic actors with the advent of advanced, flexible production."
} 
their US production facilities' costs were too high and so each cell would be provided with information to enable it to compare its individual component costs with those of its main competitor (Komatsu). What might previously have been described as management concerns (foreign exchange exposure and so on) were transferred to the workforce. Cost cutting targets were to become essential benchmarks of performance. A cost measurement mechanism was devised to disentangle "permanent" cost reductions from the effects of inflation, currency fluctuations, and shifts in volume and mix of output. Miller and O'Leary ( $p 26$ ) explain the managerial position that whilst, "the Executive Offices might propose plans and coordinate results, according to Executive Vice President Schlegel, they would not "dictate to operating units the method for reducing costs". Means of accomplishment would and should "originate within each individual organization"."

Miller and O'Leary (1994) adds important contextual detail on how different forms of knowledge and practice make "the governable person" possible (Miller and O'Leary, 1987). The case demonstrates the multiple agents involved in the neo-liberal project of entrepreneurialising workers. The agents included management consulting organisations, trade unions, and the state. The broader context, would from today's perspective, be described as deindustrialisation (although see Clarida and Hickok, 1993) financialisation (see for example, Bay et al, 2014; Cooper, 2014; Zhang and Andrew, 2014), and the widespread adoption of financial economic rationalities (Guénin-Paracini and Gendron, 2010). There was a stated "economic imperative" behind the changes -- both the US government and Caterpillar expressed concern about falling profits and threats from Japanese manufacturing which were seen to be exacerbated by a strong dollar. The "threat from Japan" has been noted by other AOS writers (for example, Armstrong, 1991; Dent, 1990; Ittner and Larcker, 1997) as a rationale for accounting change. It has been suggested that crises (manufactured and real) have been used to bring about neo-liberal changes (Klein 2007, Mirowski, 2013) or at least, to introduce neo-liberal reforms more quickly.

The Caterpillar case brought into focus two important debates (inaccurately) characterised as a debate between "the Marxists and the Foucauldians/postmodernists" which raged within the academic community during the 1990s (see for example, Armstrong, 1994; Marsden, 1998; Neimark, $1990,1994)$. One of the issues at stake was the extent to which identities (selves, subjectivities) are discursively constituted (Armstrong, 2006, 2014). The other concerned the emphasis which should be placed on the role of the economic system and the sources of power. The two are dialectically related (Arnold, 1998; Froud et al, 1998).

The extent to which accounting knowledge can produce altered subjectivities is an issue which is worthy of future research (see Armstrong, 2014). Alvesson and Karreman (2004) argue that it is important to investigate how subjectivity is formed "empirically" . Along similar lines, Arnold (1998) was concerned with the point of view of the shopfloor workers in the Caterpillar case, who in her account were very sceptical of and resistant to the management rhetoric of empowerment and economic citizenship. The subjective responses of the Caterpillar workers to the programme to make them more entrepreneurial were produced in the context of Caterpillar's cumulative \$1bn losses over the past three years and an implicit threat of more job losses. The company had closed six US plants, reducing the headcount of hourly paid workers by $44 \%$ and that of salaried staffs by 26\% (Armstrong, 2006). Arnold's (1998) Caterpillar staff interviews indicate that the workers were far more conscious of and influenced by the material threats of job loss and promises of job security than they were by abstract notions of workplace autonomy and self-actualization promised by the spatial reorganization of the plant into modular cells; the workers experienced the contradiction

\footnotetext{
${ }^{9}$ Froud et al (1998) were, to some extent, also concerned with the construction of entrepreneurial subjects noting the role of some of Miller and O'Leary's (1994) sources (for example Reich, 1991; Womack et al., 1991; Piore and Sabel, 1984; Hirst and Zeitlin, 1989) as promoters of the types of management technologies adopted by Caterpillar. They too, saw the economic as an important animator in the case.
} 
between the rhetoric of empowerment/entrepreneurialism and the insecurity they felt about their and their children's future. The Caterpillar case poses a question regarding the extent to which accounting technologies can impact upon the constitution of subjectivity. Arnold (1998) strongly suggests that the creation of human capital entrepreneurial subjects involves a whole lot more than managerial control system changes.

One of the concerns of Ahrens and Chapman (2007) study of a restaurant business is to discover the methods used to enable entrepreneurial behaviour on the part of the restaurant managers. It was noted that head office managers were sensitive to the benefits of an approach to management control that sought to reckon with the intelligence of managers - to enable them to act as entrepreneurs. Ahrens and Chapman (2007) sees the subjectivities of the employees as changing through the construction of arrays of activity by area managers that incorporate corporate objectives with the restaurant managers' personal understandings. This research did not see individuals as being "captured" by the performance metrics. Rather, that by actively working with other organisational members, the metrics were drawn upon in order to establish a shared understanding of what it meant to do well. For the neo-liberal entrepreneurial subject, the meaning of doing well is to maximize returns on their human capital. With this understanding the restaurant case reveals the contradiction that entrepreneurial subjects can be entrepreneurial for themselves (against the interests of their employer). Ahrens and Chapman (2007) noted that very good chefs could extract high salaries from their restaurant managers, just as commercially successful restaurant managers could attain legendary status even if there was widely shared, but unproven, suspicion that they "ripped off the company" by keeping a share of the revenues to themselves. Perhaps this was a price the restaurant company was prepared to pay for innovative, profitable staff.

The second debate invoked by the Caterpillar case - the importance of the "economic system" cannot be ignored. This is not "dogma" - it is the contention here that capitalism shapes the world. There are imperatives that issue from the systemic drives of capitalism including the imperatives of cheapening labour, expanding markets, economic growth, and constant renovations in production to generate profit, and so forth. As Brown (2015) cogently argues, if capitalism is omitted in any social analysis, it will not be possible to grasp the intricate dynamics between political rationality and the economic constraints, and it will be impossible to grasp the extent and depth of neoliberalism's power in making this world and unfreedom within it. With respect to the Caterpillar case, Arnold (1998) argued that by abandoning historical materialism accounting research would lose its ability to confront the problems posed by capitalism. While Froud et al (1998)'s reflection on the Caterpillar case maintained an understanding of the importance of profitability by arguing that the first material legacy of the changes at Caterpillar was a modest increase in outsourcing, this was followed by massive reinvestment which left Caterpillar with re-equipped factories that could not work profitably under existing labour contracts ${ }^{10}$. The drives of capitalism do not negate the importance of understanding the neo-liberal conception of humans as entrepreneurial capital units, but, any analysis of the rationalities of neo-liberalism need to be set within the context of the imperatives of capitalism.

The Caterpillar case demonstrates the social contradictions brought about by the drive to entrepreneurialize staff while at the same time needing to control them. Although individual work groups met regularly with management to share ideas about how to make things more cheaply and

\footnotetext{
${ }^{10}$ Arnold (1998) notes that the economic context is used both to invoke co-operation as well as being used coercively. Arnold, 1998, p 674 states that “..., labour must concede flexibility in order to prevent capital flight. Thus, union-management cooperation programs and concession bargaining represent two faces of the same factory regime; a regime that is built not only on consent, as emphasized in Miller and O'Leary's notion of "economic citizenship," but equally on concession bargaining or, as Burawoy (1985, p. 127) terms it, "consent to sacrifice."”
} 
quickly, the workforce did not staff the planning departments nor make strategic decisions. One worker reported that after working hard to find ways to produce a particular component as cheaply as possible "...finally the company admitted to us, when we really pinned them down ... they said, well, the truth of the matter is that we need the space - we are moving something else into that area and if you could do it for free, we'd still have to send it out" (Arnold, 1998, p 677). This one small episode reflects the complex and contradictory nature of management control technologies targeted at entrepreneurial subjects.

\section{The complexity and contradictions of management control technologies in practice}

Other work in AOS has emphasised that in spite of the change in the targets of management control systems (towards individuals and teams), there remains the need for management to maintain its control over both labour productivity and costs. Briers and Chua's (2001) study of an Australian Aluminium Company demonstrates how the company management came under the sway of an international consulting firm and Australian state initiatives to "modernise" by acquiring an ABC system. It sets out a fascinating picture of management as a semi chaotic and complex process. Two features seem to dominate the case, the first was the overwhelming desire by management "to find the facts" and secondly (and materially), that the rationality behind ABC's acceptance was contingent on the figures it produced (whether correct or not) making the recommendation for the discontinuance of a recalcitrant machine. In short, acceptance of $A B C$ depended upon it producing figures to support desired decisions.

The acquisition of the $A B C$ system took place amid the Australian state promotion of 'performance enhancing' techniques like JIT/TQM. One industrial engineer stated that the real driver behind the introduction of these new techniques was cycle time -- a euphemism for work intensification (Green and Yanarella, 1996). Throughout the paper we can see seeds and reflections of an increase in individual worker accounting controls - described in the case as "prompt and reliable people related information" (including the incurrence of sick leave). While Briers and Chua's (2001) study is seemly concerned with the acquisition of new management accounting technology (an ABC system), it appears that the management were concerned more with "old fashioned" cost control, and valorisation of labour than with reconstructing the subjectivities of the workforce.

Although Johnson and Kaplan (1987) argue the case for more accurate accounting information (through ABC), Hopper and Armstrong (1991) counter that if management is taken to be about the control of labour and of junior managers, the issue is more complex. This is not to argue that "accurate costs" are not important to management but that, management accounting information is to be judged by the results which it achieves, rather than its notional accuracy. For example, the classical literature on the behavioural aspects of budgets (e.g. Caplan, 1971) discusses the effects of setting targets at various levels of difficulty, not whether these levels are "correct" in some essential sense. Thus, the accuracy of budgets and internal attributions of cost might be regarded as irrelevant, so long as they serve to focus managerial effort in the directions desired by those who control the organisation. This resonates with Alvesson and Karreman (2004) whose case study of a global consulting firm (Global) found that managers insisted that staff report working for eight hours a day irrespective of the number of additional hours they work. This was because labour-hours is an important constituent of a key ratio by which management was judged -- the project margin. In spite of a key component of the information system being entirely wrong, the management control system in this company "worked" (for shareholders and senior management) in the sense that for many staff, 70 hours weeks were the norm. In some ways this is indicative of strongly neo-liberal rationality. While under liberalism labour was a commodity to be purchased by the hour, under neoliberalism, staff are human capital units who provide a service and receive an income. 
Alvesson and Karreman (2004) argue that almost all control practices in Global include aspects of cultural engineering more or less geared towards the subjectivities of the staff. The control systems take many different forms and are both financial and non-financial. Socio-ideological controls feature strongly. From the theoretical perspective of bio-politics, Global's socio-ideological controls would have been enhanced by neo-liberalism's entrepreneurial rationalities. Employees in the study expressed a strong desire to succeed. The idea of being successful in a certain way is an outcome of social processes which extends beyond the boundaries of individual organisations. In Global, success is equated with promotion speed, ranking, job titles, monetary and rewards; each of these could be seen as Lacanian mirrors. Work in AOS (Roberts 1990, 1991, 2009) suggests that people are animated to maintain and enhance their self-esteem and their sense of security and this can be exploited by forms of power which offer control as a sense of security.

The AOS work in this section presents a complex picture of attempts by management to organize and control labour and understand the costs of their activities. These management concerns might have led companies (on the advice of consultants) to adopt new technical forms of accounting and control systems but the concerns of management and the contradictions of capitalism remain substantively the same as when AOS began 40 years' ago. Although Caterpillar management claimed that it would not dictate to cells the method for reducing costs; nonetheless, the workforce did not have the option but to try to reduce costs. Attempts by management to deliver value by exploiting the skill and expertise of its workforce in the work discussed here (particularly Ahrens and Chapman, 2007; Miller and O'Leary, 1994) echoes scientific management's appropriation of worker knowledge. What is clear from the AOS work discussed in this section is that management accounting control systems act upon many workers intensively and continuously. This reflects critical HR research what has found that organisational life for many is dominated by an unprecedented micro-measurement and management of individual performance (see for example, Carter et al, 2013; Scholarios and Taylor, 2014; Stewart et al, 2010). Controls aimed at changing the subjectivity of workers have been adopted unevenly ${ }^{11}$ and their success at doing so remains an open question. Resistance to entrepreneurialism is discussed further in the next section.

\section{Resistance to neo-liberalism}

Employees from many different industries and organisational levels, who are increasingly harangued to be "more entrepreneurial" (eg academics now have to raise funding, sell knowledge, deliver conferences, improve their personal ranking and so on) while at the same time subjected to increasingly detailed control systems, are finding work, if not a living death, a cause of anxiety/stress. The academic literature offers few avenues of resistance. Arnold (1998) notes the importance of trade unions and community in resisting the pressure of neo-liberalism, while other work attacks and lays-bare neo-liberalisms rationalities. This stream of work in AOS will be considered first.

\section{The feminine and sexuality}

Shearer and Arrington (1993), drawing from the work of Luce Irigaray and her feminist deconstruction of Freudian and Lacanian work, while not specifically addressing biopolitics, drives a critical wedge into its rationalities, by suggesting that entreprenuerialism is masculine and animated

\footnotetext{
${ }^{11}$ See for example Taylor (2013) which argues the performance management systems have been implemented with particular robustness in the finance industry.
} 
by phallic desire (Burrell, 1987 ${ }^{12}$; Cooper, 1992). Irigaray reads Western sexuality, economics and politics as beginning with some notion of desire. To her, according to Western rationalities all desire is reduced to a singularity - phallic desire (for example under neo-liberalism, we all deemed to have the same single desire - to maximize returns on ourselves) and so society is reducible to a linear aggregation of humans with the same desire. What Irigaray challenges is the way in which the phallocratic character of both sexuality and economics, excludes from view the possibility of a multiplicity of desires and values (sexual desire as something other than penile/phallic desire and economics as something other than appropriative self-interest). Shearer and Arrington (1993) argue that inasmuch as accounting is discourse, an enactment of a particular language of economic activity, it codifies and orchestrates economic participation in accordance with a telos that governs the place of participants in the economy.

Shearer and Arrington (1993) argue that the "erasure" of humanity is explained by Marxist theory the value of the thing-in-itself is liquidated through a singular telos of its value in exchange, exchange for capital. They go on to state (p263/4), "To be in the economy is to subject one's self to the grammar of accounting, ... It is to be assigned a role as inscribed within the numbers, norms and variances of accounting, to be marked as efficient or inefficient, as acceptable or deviant ... which always, without exception, takes as its telos the efficient exchange of the self for capital." Thus Shearer and Arrington (1993) set out an understanding of accounting as an objectifier of humanity. To objectify a human being in the name of teleology (efficiency, profit etc), is to presume that human value and desirability is enhanced when it takes a form other than its own. According to the teleology of neo-liberalism, humans are valuable if they earn the maximum return on themselves - if they are not productive (in a very specific sense of the word), they are not valuable. A human being is no longer the subject of her own value or her own desires. She is an object of the telos presumed to govern her from outside of herself. Resistance means rejecting this telos and embracing the rich life-affirming flows of multiplicity. Shearer and Arrington (1993) proposes that our bodies are not human capital - they are multiple sites of pleasure.

In a similar vein, Roberts (2005) offers the insight that when confronted by performance metrics, one should not fall into the Lacanian mirror but remember that we are not our performance metrics - we are much more complex and wonderful than the ludicrous, impoverished reflection which they offer. Roberts $(1990,1991)$ suggests that socialising (rather than hierarchical) accountability offers a more complete recognition of self. Roberts, (1991, p 363), states that there is "a form of organizational talk which constantly threatens to dissolve the preoccupation with the objective boundaries of self which hierarchical accountability encourages, and instead offers a confirmation of self as active subject, different from yet in a relation of interdependence on others." Arnold (1998) sees trade unions as an important socialising conduit for the resistance of neo-liberal rationalities.

\section{Trade unions and material circumstances}

Arnold (1998, p 678) argues, that people "not only reflect, understand and interpret their situations in terms of traditions and class solidarities, they also integrate their experiences at work into other aspects of their personal lives as parents, family, and community members". In a similar vein, Ezzamel et al (2004) highlight the importance of employees in shaping the production process. Armstrong (1994) notes that research (eg Nichols and Beynon, 1977; Burawoy, 1979) has shown very little sign of the supposed saturation on workers' consciousness by the discourse and practices of disciplinary power. Workers have always created their own language, rhetoric, and symbols, often

\footnotetext{
12 Burrell (1987) saw accounting and sexuality as being diametrically opposed. Taking a broader view of management control, Burrell saw the accounting of time and of the body as the suppression and repression of (sexual) interrelationships which threaten rational-calculative techniques.
} 
appropriating the management vocabularies, subverting meanings, and adding irony and sarcasm. So, for example, in the Caterpillar case, the "Plant With a Future" (PWAF) was dubbed the "Plant with a Fence" to denote the security-fence erected around the plant to protect it from protests. The union-management-cooperation-program, "Employee Satisfaction Process" (ESP), converted to "Easily Suckered People." Caterpillar's listing of protected jobs, --"secured employee list" became the "shrinking employee list" ${ }^{13}$.

\section{Conclusion}

The neo-liberal vision of humanity as individual enterprise units whose sole value is in their ability to produce an income stream is horrific. This is a vision in which our most human characteristics (empathy, compassion, sexuality, and so on) are not considered to be valuable unless someone is willing to pay for them. Humans lose their standing as simply being valuable as humans who should be granted equal rights and respect. It is not suggested here that the neo-liberal view perspective is universally shared, internalised or indeed adopted; the neo-liberal project is incomplete and profound social understandings are slow to change. However, it is a rationality which a range of powerful institutions are working very hard to promote, sell and use. The neo-liberal rationality that the state should not pursue social welfare policies means that many citizens are being left without social support and this brings a material force to attempts to create more entrepreneurial subjects. In accounting, new management control strategies and technologies are being developed (Davila et al, 2009), sold and adopted on the basis that they facilitate "undeniably moral" entrepreneurialism among staff. This may be described at the ultimate neo-liberal moment in which organisations use the rhetoric of ethical business while their workforce suffer from increased workloads, intense work measurement, unprecedented discipline, stress and the fear of "managed exit" (Cederstrom and Fleming, 2012; Malsch 2013).

The work in AOS reviewed here has done an outstanding job in charting accounting changes from systems concerned with costs to ones oriented towards micro-measurement, micro management, ratings, rankings and scores. It highlights the roles of management consultants in selling and globally dispersing control technologies; the role of the state in promoting the technologies and rationalities of neo-liberalism; the role of agency theory and its relationship to control systems; the possibilities for different forms of resistance; the contradictions of capitalism and its antagonistic nature which no management control system can overcome; the fleeting satisfactions which management control systems can give to managers; and how management control systems can individualise and create anxiety.

In order for AOS to continue to fulfil its aim to be "concerned with all aspects of the relationship between accounting and human behaviour, organizational structures and processes, and the changing social and political environment of the enterprise", there is a need for more research which considers the perspective of employees at all levels of the organisational hierarchy. Future research should be mindful of the gender, race, sexuality and age related concerns associated with the impact of management control; all of these are disappointingly absent from AOS thus far. There is little in AOS which sees work as the "living death" described so powerfully by Cederstrom and Fleming (2012). In this respect too it would be wonderful to have more case studies which empathise with humans, instead of seeing them as targets of various forms of stimuli designed to make them work harder. It is also essential that AOS research does not accept the status quo as given, and continues to question the legitimacy of the power and takes class as the analytic basis for alienation and exploitation.

\footnotetext{
${ }^{13}$ As McNally (1995, pp. 23-24) observes, such linguistic inversions are neither arbitrary nor random; they are typical of shop floor "cultures of resistance".
} 
Abernethy, M. A. and Brownell, P. (1997). Management control systems in research and development organizations: The role of accounting, behavior and personnel controls. Accounting, Organizations and Society 22(3-4): 233-248.

Abernethy, M. A. and Brownell, P. (1999). The role of budgets in organizations facing strategic change: an exploratory study. Accounting, Organizations and Society 24(3): 189-204

Abernethy, M. A. and A. M. Lillis. (1995). The impact of manufacturing flexibility on management control system design. Accounting, Organizations and Society 20(4): 241-258.

Adler, P. S. and C. X. Chen. (2011). Combining creativity and control: Understanding individual motivation in large-scale collaborative creativity. Accounting, Organizations and Society 36(2): 63-85.

Ahrens, T. and C. S. Chapman. (2007). Management accounting as practice. Accounting, Organizations and Society 32(1-2): 1-27

Alvesson, M. and Karreman, D. (2000) 'Varieties of Discourse: On the Study of Organizations Through Discourse Analysis', Human Relations 53(9): 1125-49.

Armstrong P., (1985). Changing management control strategies: The role of competition between accountancy and other organisational professions, Accounting, Organizations and Society, 10(2), $129-148$

Armstrong, P. (1987). The rise of accounting controls in British capitalist enterprises. Accounting, Organizations and Society, 12(5), 415-436.

Armstrong, P., (1991), Contradiction and Social Dynamics in the Capitalist Agency Relationship, Accounting, Organizations and Society, 16(1), $1-25$

Armstrong, P., (1994). The Influence of Michel Foucault on Accounting, Critical Perspectives on Accounting, Volume 5/1, 25-55

Armstrong, P., (2006). Ideology and the grammar of idealism: The Caterpillar controversy revisited, Critical Perspectives on Accounting, 17/5, 529 - 548

Armstrong P. (2014), The discourse of Michel Foucault: A sociological encounter. Critical Perspectives on Accounting,

Arnold, P.J., (1988). The limits of postmodernism in accounting history: The Decatur experience, Accounting, Organizations and Society, 23(7), 665-684

Arnold, P. J., (2009). Global financial crisis: The challenge to accounting research, Accounting, Organizations and Society, 34, 803-809

Arnold, P. J., (2012). The political economy of financial harmonization: The East Asian financial crisis and the rise of international accounting standards, Accounting, Organizations and Society, 37/6, 361381

Artz, M., Homburg, C., and Rajab, T., (2012), Performance-measurement system design and functional strategic decision influence: The role of performance-measure properties, Accounting, Organizations and Society, 37(7), 445-460 
Baiman, S., (1990), Agency research in managerial accounting: A second look. Accounting, Organizations and Society, 15(4), $341-371$

Bay, C., Catasús, B., Johed, G. (2014), Situating financial literacy, Critical Perspectives on Accounting, 25(1), $36-45$

Bisbe, J. and D. Otley. (2004). The effects of the interactive use of management control systems on product innovation. Accounting, Organizations and Society 29(8): 709-737.

Boedker, C., and Chua, W F., (2013). Accounting as an affective technology: A study of circulation, agency and entrancement, Accounting, Organizations and Society 38: 245 - 267

Boltanski, L., and Chiapello E., (2005) The New Spirit of Capitalism' London: Verso

Braverman, H., (1974), Labour and Monopoly Capital, New York: Monthly Review Press

Briers, M. and W. F. Chua. (2001). The role of actor-networks and boundary objects in management accounting change: A field study of an implementation of activity-based costing. Accounting, Organizations and Society 26(3): 237-269

Brown, W., (2015). Undoing the Demos: Neoliberalism's Stealth Revolution, New York: Zone Books

Burawoy, M., (1979).; Manufacturing consent: changes in the labor process under monopoly capitalism. Chicago: University of Chicago Press

Burawoy, M., (1985). The Politics of Production, London: Verso

Burrell, G., (1987). No accounting for sexuality. Accounting, Organizations and Society. 12(1), 89-101.

Burrell G., (1979). Sociological paradigms and organisational analysis elements of the sociology of corporate life, London: Heinemann Educational

Cadez, S., Guilding, C., (2008) An exploratory investigation of an integrated contingency model of strategic management accounting, Accounting, Organizations and Society, 33,(7-8), 836-863.

Çalışkan, K., and Callon, M., (2009). Economization, part 1: shifting attention from the economy towards processes of economization. Economy and Society. 38/3: 369-398

Çalışkan, K., and Callon, M., (2010). Economization, part 2: a research programme for the study of markets. Economy and Society. 39/1: 1-32

Callon, M., (2009). Civilizing markets: Carbon trading between in vitro and in vivo experiments, Accounting, Organizations and Society, 34/3-4, 535-548

Caplan, E. H., (1971). Management Accounting and Behavioural Science, Addison-Wesley: Reading Mass.

Carter, R., Danford, A., Howcroft, D., Richardson, H., Smith, A. and Taylor, P. (2013) 'Workers' experience of occupational ill-health in lean clerical work', Work, Employment and Society, 27.5 
Cederstrom, C., and Fleming, P., (2012), Dead Man Working, Zero: Winchester

Chabrak, N., (2014). The shareholder value mythology and the market "communion", Law and Financial Markets Review 8(1)

Chenhall, R. H., (2003). Management control systems design within its organizational context: findings from contingency-based research and directions for the future, Accounting, Organizations and Society, 28(2-3), 127-168

Chenhall, R. H. and K. Langfield-Smith. (1998). The relationship between strategic priorities, management techniques and management accounting: An empirical investigation using a systems approach. Accounting, Organizations and Society 23(3): 243-264

Cherns, A. B., (1978). Alienation and accountancy, Accounting, Organizations and Society, 3(2), 105114

Clarida, R. H. and Hickok, S. (1993), US Manufacturing and the Deindustrialisation Debate. World Economy, 16: 173-192

Clawson, D., 1980, Bureaucracy and the Labour Process, Monthly Review Press

Collier, P.M., (2005), Governance and the quasi-public organization: A case study of social housing. Critical Perspectives on Accounting

Cooper, C., (1992), The Non and Nom of Accounting for (M)other Nature, Accounting, Auditing and Accountability Journal, 5(3), 16 - 39

Cooper, C., (2015), Accounting for the fictitious: a Marxist contribution to understanding accounting's roles in the financial crisis, Critical Perspectives on Accounting, 30, $63-82$

Cooper, C., and Taylor, P., (2000). From Taylorism to Mrs Taylor: The transformation of the Accounting Craft, Accounting Organisations, and Society, 25(6), 555-578

Cooper, C., and Taylor, P., (2005). Independently verified reductionism: Prison Privatisation in Scotland, Human Relations, 58(4), 467-522

Cooper, D., (1980). Discussion of Towards a Political Economy of Accounting, Accounting, Organizations and Society, pp. 161-166

Cooper, D., (1981) A Social and Organizational View of Management Accounting, in M. Bromwich, A.G. Hopwood (Eds.), Essays in British Accounting Research, Pitman

Cooper, D., and Sherer, M., (1984), The value of corporate accounting reports: Arguments for a political economy of accounting, Accounting, Organizations and Society, 9(3-4), 207-232

Covaleski, M., and Aiken, M., (1986), Accounting and theories of organizations: Some preliminary considerations, Accounting, Organizations and Society, Volume 11, Issues 4-5, Pages 297-319

Covaleski, M. A., Dirsmith, M. W., and Weiss, J. M., (2013). The social construction, challenge and transformation of a budgetary regime: The endogenization of welfare regulation by institutional entrepreneurs, Accounting, Organizations and Society, 38/5, 333-364 
Dambrin, C., Robson, K., (2011). Tracing performance in the pharmaceutical industry: Ambivalence, opacity and the performativity of flawed measures, Accounting, Organizations and Society, 36(7), 428-455

Davila, A., G. Foster and M. Li. (2009). Reasons for management control systems adoption: Insights from product development systems choice by early-stage entrepreneurial companies. Accounting, Organizations and Society 34(3-4): 322-347.

Davila, T. (2000). An empirical study on the drivers of management control systems' design in new product development. Accounting, Organizations and Society 25(4-5): 383-409

Dent, J. F. (1990). Strategy, organization and control: Some possibilities for accounting research. Accounting, Organizations and Society 15(1-2): 3-25.

Dermer, J. (1990). The strategic agenda: Accounting for issues and support. Accounting, Organizations and Society 15(1-2): 67-76

Ditillo, A. (2004). Dealing with uncertainty in knowledge-intensive firms: The role of management control systems as knowledge integration mechanisms. Accounting, Organizations and Society 29(34): 401-421.

Di Vittorio, P. (2005). De la psychiatrie à la biopolitique, ou la naissance de l'état bio-sécuritaire, In « Michel Foucault et le contrôle social », sous la direction d'Alain Beaulieu, PU Laval.

Dixon, K., Gaffikin, M. (2014), Accounting practices as social technologies of colonialistic outreach from London, Washington, et Cetera, Critical Perspectives on Accounting, 25(8), 683-708.

Edgley, C., (2014), A genealogy of accounting materiality, Critical Perspectives on Accounting, 25(3), 255-271.

Eisenhardt, K., (1985), Control: Organisational and Economic Approaches, Management Science, 134-149

Eisenhardt, K., (1988), Agency and Institutional Explanations of Compensation in Retail Sales. Academy of Management Journal. 488-511

Ezzamel, M.,Willmott, H., and Worthington, F., (2004) Accounting and management-labour relations: the politics of production in the 'factory with a problem' Accounting, Organizations and Society, 29/3-4, 269-302

Farjaudon, A. and Morales, J. (2013), In search of consensus: The role of accounting in the definition and reproduction of dominant interests. Critical Perspectives on Accounting, 24(2), 154-171.

Fourcade, M., and Healy, K., (2013). Classification situations: Life-chances in the neoliberal era, Accounting, Organizations and Society, 38/8 559-572

Foucault, M., (2010), The Birth of Biopolitics: Lectures at the Collège de France, translated by Graham Burchill, Palgrave Macmillan: Houndmills, Hampshire 
Froud, J., K. Williams, C. Haslam, S. Johal and J. Williams. (1998). Caterpillar: Two stories and an argument. Accounting, Organizations and Society 23(7): 685-708.

Gerdin, J., (2005). Management accounting system design in manufacturing departments: an empirical investigation using a multiple contingencies approach, Accounting, Organizations and Society, 30(2), 99-126

Gerdin, J., Greve, J., (2004). Forms of contingency fit in management accounting research-a critical review, Accounting, Organizations and Society, 29(3-4), April-May 2004, Pages 303-326

Gerdin, J., Greve, J., (2008). The appropriateness of statistical methods for testing contingency hypotheses in management accounting research, Accounting, Organizations and Society, 33(7-8), 995-1009.

Govindarajan, V. (1988). A contingency approach to strategy implementation at the business-unit level: integrating administrative mechanisms with strategy. Academy of Management Journal, 828853.

Govindarajan, V. and A. K. Gupta. (1985). Linking control systems to business unit strategy: Impact on performance. Accounting, Organizations and Society 10(1): 51-66.

Grafton, J. Lillis, A.M. and Widener, S.K., (2010), The role of performance measurement and evaluation in building organizational capabilities and performance. Accounting, Organizations and Society, 35 (7), pp. 689-706.

Grant, D., Keenoy, T. and Oswick, C. (eds) (1998) Discourse and Organization. London: Sage

Green, W.C., Yanarella, E. J., (1996) North American Auto Unions in Crisis: Lean Production as Contested Terrain, State University of New York Press: Albany

Guénin-Paracini, H., Gendron, Y. (2010), Auditors as modern pharmakoi: Legitimacy paradoxes and the production of economic order, Critical Perspectives on Accounting, 21 (2), $134-158$

Habersam, M., Piber, M., Skoog, M. (2013). Knowledge balance sheets in Austrian universities: The implementation, use, and re-shaping of measurement and management practices, Critical Perspectives on Accounting, 24(4-5), $319-337$

Haka, S. F., (1987), Capital budgeting techniques and firm specific contingencies: A correlational analysis, Accounting, Organizations and Society, 12(1), 31-48

Hammond, T., Clayton, B.M., and Arnold, P.J. (2012), An " unofficial" history of race relations in the South African accounting industry, 1968-2000: Perspectives of South Africa's first black chartered accountants, Critical Perspectives on Accounting, 23(4-5), 332-350.

Hardt, M. and Negri, A., (2001) Empire, Cambridge: Harvard University Press

Hardy, C., Palmer, I. and Philips, N. (2000) 'Discourse as a Strategic Resource', Human Relations 53(9): 1227-48. 
Hartmann, F. G. H., Moers, F., (1999). Testing contingency hypotheses in budgetary research: an evaluation of the use of moderated regression analysis, Accounting, Organizations and Society, 24(4), 291-315

Henri, J-F., (2006), Management control systems and strategy: A resource-based perspective, Accounting, Organizations and Society, 31(6) 529-558

Herzberg, F. (1968), One more time: How do you motivate employees? Harvard Business Review. 46(1), 53-62.

Hirst, P., and Zeitlin, J., (1989). Reversing Industrial Decline. Oxford: Berg

Ho, J. L.Y., Wu, A. Wu, S. Y.C., (2014). Performance measures, consensus on strategy implementation, and performance: Evidence from the operational-level of organizations, Accounting, Organizations and Society, 39(1), 38-58

Hopper, T., and Armstrong, P., (1991). Cost Accounting, Controlling Labour and the Rise of Conglomerates. Accounting, Organizations and Society, 16(5-6), 405 - 438

Hopper T., Cooper, D., Lowe, T., Capps, T., Mouritsen, J., (1986) Management Control and Worker Resistance in the National Coal Board, in Knights, D., Willmott, H., (Eds.), Managing the Labour Process, Gower, London

Hopwood, A., (1987). The archaeology of accounting systems, Accounting, Organizations and Society, $12 \quad$ (3), 207-234

Hoskin, K., and Macve, R. (1986), Accounting and the examination, 11(2), 561-593

Ittner, C. D. and D. F. Larcker. (1997). Quality strategy, strategic control systems, and organizational performance. Accounting, Organizations and Society 22(3-4): 293-314.

Ittner, C. D., D. F. Larcker and T. Randall. (2003). Performance implications of strategic performance measurement in financial services firms. Accounting, Organizations and Society 28(7-8): 715-741.

Jansen, E.P., Merchant, K.A., Van der Stede, W.A. (2009). National differences in incentive compensation practices: The differing roles of financial performance measurement in the United States and the Netherlands, Accounting, Organizations and Society, 34(1), $58-84$

Jupe, R., (2012). The privatization of British Energy: Risk transfer and the state, Accounting, Organizations and Society, 37/ 2, 116-129

Kaplan, R. S., and Johnson, H. T. (1987). Relevance Lost: The Rise and Fall of Management Accounting. Boston: Harvard Business School Press

Klein, N., (2007). The shock doctrine: the rise of disaster capitalism. London : Allen Lane

Knights, D., \& Collinson, D. (1987). Disciplining the shopfloor: a comparison of the disciplinary effects of managerial psychology and financial accounting, Accounting, Organizations and Society, 12(5), 457-477. 
Kosnick, R., (1987), Greenmail: a Study in Board Performance in Corporate Governance, Administrative Science Quarterly. 163-185

Lacan, J., (1979), The Four Fundamental Concepts of Psycho-analysis. Harmondsworth: Penguin

Langfield-Smith, K. (1997). Management control systems and strategy: A critical review. Accounting, Organizations and Society 22(2): 207-232

Lehman, C.R. (2013), Knowing the unknowable and contested terrains in accounting. Critical Perspectives on Accounting, 24(2), 136-144.

Lehman, C., and Tinker, T., (1987). The "real" cultural significance of accounts, Accounting, Organizations and Society, Volume 12, Issue 5, Pages 503-522

Loft, A., (1986), Towards A Critical Understanding Of Accounting - The Case Of Cost Accounting In The UK, 1914-1925, Accounting, Organizations and Society, 11(2),

Malsch, B., (2013). Politicizing the expertise of the accounting industry in the realm of corporate social responsibility. Accounting, Organizations and Society, 38(2), 149-168

Marsden, R., (1998). A political technology of the body: how labour is organized into a productive force, Critical Perspectives on Accounting, 9/1, 99-136

McNally, D., (1995). Language History and Class Struggle, monthly Review, 47, 13 - 30

Merchant, K. A., (1984). Influences on departmental budgeting: an empirical examination of a contingency model, Accounting, Organizations and Society, 9, (3-4), 291-307

Merino, B., and Neimark, M., (1982). Disclosure Regulation and Public Policy: A Sociohistorical Appraisal, $33-57$

Miller, P., and Napier, C., (1993). Genealogies of Calculation, Accounting, Organizations and Society, $18(7 / 8), 631-647$

Miller, P., and O'Leary, T., (1987). Accounting and the construction of the governable person, Accounting, Organizations and Society, 12(3), 235-265

Miller, P. and T. O'Leary. (1994). Accounting, "economic citizenship" and the spatial reordering of manufacture. Accounting, Organizations and Society 19(1): 15-43.

Mirowski, P., (2013). Never let a serious crisis go to waste: how neoliberalism survived the financial meltdown, London : Verso

Montgomery, D., (1979), Workers' Control in America. Studies in the History of Work, Technology and Labor Studies, Cambridge: Cambridge University Press

Montgomery, D., (1987). The Fall of the House of Labour: The Workplace, the State and American Labor Activism, Cambridge: Cambridge University Press

Muniesa, F., and Linhardt, D., (2011). Trials of explicitness in the implementation of public management reform, Critical Perspectives on Accounting, 22/6, 550-566 
Neimark, M., (1990). The king is dead. Long live the king! Critical Perspectives on Accounting, 1/1, 103-114

Neimark, M. K., (1994). Regicide Revisited: Marx, Foucault and Accounting, Critical Perspectives on Accounting, $5 / 1,87-108$

Neimark, M., and Tinker, T., (1986). The social construction of management control systems, Accounting, Organizations and Society, Volume 11, Issues 4-5, Pages 369-395

Nelson, D., (1974). Scientific Management, Systematic Management and Labor, 1880 - 1915, Business History Review, $479-500$

Nichols T., and Beynon, H., (1977), Living with Capitalism, London: Routledge

O'Doherty, D., and Willmott, H., (2002), Debating Labour Process Theory: The Issue of Subjectivity and the Relevance of Post-structuralism, Sociology, 35(2): 457 -76

Otley, D. T. (1980). The contingency theory of management accounting: Achievement and prognosis. Accounting, Organizations and Society 5(4): 413-428.

Perera, S., Harrison, G., Poole, M. (1997). Customer-focused manufacturing strategy and the use of operations-based non-financial performance measures: A research note, Accounting, Organizations and Society, 22(6), 557-572

Piketty, T., (2014) Capital in the Twenty-First Century, translated by Arthur Goldhammer, London: The Belknap Press of Harvard University Press

Piore, M., and Sabel, C., (1984). The Second Industrial Divide. New York: Basic Books

Poon, M., (2009). From new deal institutions to capital markets: Commercial consumer risk scores and the making of subprime mortgage finance, Accounting, Organizations and Society, 34/5, 654-674

Reich, R. B., (1991). The Work of Nations. New York: Knopf

Reyes-Zaga, H A., Biopolitics and Disposable Bodies: A Critical Reading of Almazán's Entre perros, Translated by Mariana Ortega Breña, Latin American Perspectives, 41, 189 - 201

Roberts, J., (1990). Strategy and Accounting in a UK Conglomerate, Accounting, Organizations and Society, 15(1/2), $107-124$

Roberts, J., (1991). The Possibilities of Accountability, Accounting, Organizations and Society, 16/4 $355-368$

Roberts, J.,(2005). The Power of the "Imaginary" in Disciplinary Processes, Organization, 12(5), 619 642

Roberts, J., (2009), No one is perfect: The limits of transparency and an ethic for "intelligent" accountability, Accounting, Organizations and Society, 34, 957-970.

Samuel, S., Dirsmith, M. W., McElroy, B., (2005) Monetized medicine: from the physical to the fiscal, Accounting, Organizations and Society, 30/3, 249-278 
Scholarios, D. and Taylor,P. (2014 forthcoming) 'Decommissioned Vessels' - Performance Management and Older Workers in Technologically-intensive Service Work, Technological Forecasting and Social Change,vol.88

Selto, F. H., Renner, C. J., Young, S. M., (1995). Assessing the organizational fit of a just-in-time manufacturing system: Testing selection, interaction and systems models of contingency theory, Accounting, Organizations and Society, 20(7-8), 665-684

Shearer, T., and Arrington, C. E., (1993), Accounting in other wor(I)ds: A feminism without reserve. Accounting, Organizations and Society, 18(2-3), 253-272

Shields, J. F. and M. D. Shields. (1998). Antecedents of participative budgeting. Accounting, Organizations and Society 23(1): 49-76.

Simons, R. (1987). Accounting control systems and business strategy: An empirical analysis. Accounting, Organizations and Society 12(4): 357-374.

Simons, R. (1990). The role of management control systems in creating competitive advantage: New perspectives. Accounting, Organizations and Society 15(1-2): 127-143.

Stewart, P., Murphy, K., Danford, A., Richardson, T., Richardson, M. and Wass, V. (2010) 'We Sell Our Time No More': Workers' Struggles Against Lean Production in the British Car Industry, London: Pluto Press

Taylor, P., and Cooper, C., (2008). It was absolute hell: Inside the private prison, Capital and Class, $96,3-30$

Taylor, P., (2013) Performance Management and the New Workplace Tyranny - A Report for the Scottish Trades Union Congress, Glasgow: STUC

http://www.stuc.org.uk/files/Document\%20download/Workplace\%20tyranny/STUC\%20Performanc e\%20Management\%20Final\%20Edit.pdf

Tinker, A.M. (1980), Towards a Political Economy of Accounting: An Empirical Illustration of the Cambridge Controversies, Accounting, Organizations and Society (1980), pp. 147-160

Tinker A.M., Merino, B.D., Neimark. M.D., (1982), The Normative Origins of Positive Theories: Ideology and Accounting Thought, Accounting, Organizations and Society (1982), 5(2), 167-200

Toms, S., (2005). Financial control, managerial control and accountability: evidence from the British Cotton Industry, 1700-2000, Accounting, Organizations and Society, Volume 30, Issues 7-8, Pages 627-653

Upton, D.R., Arrington, C.E. (2012), Implicit racial prejudice against African-Americans in balanced scorecard performance evaluations. Critical Perspectives on Accounting, 23(4-5), 281-297.

Virno, P. (2004) The Grammar of the Multitude (trans. Isabella Bertoletti, James Cascaito, and Andrea Casson), Semiotext(e), Los Angeles.

Womack, J., Jones, D., and Roos, D., (1991), The Machine that Changed the World, New York: Rawson 
Zhang, Y., and Andrew, J., (2014) Critical Perspectives on Accounting, 25(1), 17-26

Žižek, S. (2000). The Ticklish Subject: the Absent Centre of Political Ontology, London and New York: Verso. 